\title{
The Effect of Social Media Marketing on Purchase Decision with Brand Awareness as Mediation on Haroo Table
}

\author{
Angelyn $^{1}$, David Sukardi Kodrat ${ }^{2}$ \\ School Of Business and Management, Universitas Ciputra, Citraland CBD Boulevard, \\ Surabaya, Indonesia-602198, \\ angelyn01@magister.ciputra.ac.id \\ david.kodrat@ciputra.ac.id \\ https://doi.org/10.37715/ rmbe.v1i1.1946.g1548
}

\begin{abstract}
Haroo Table is an online bakery shop in Surabaya. Haroo Table's promotional activities turns out is not enough to make company become the first choice because of competitors that has higher brand awareness. The purpose of this research is to find out the effect of social media marketing on purchasing decisions with brand awareness as mediation on Haroo Table. The population in this research is 112 people who following Haroo Table's Instagram and make transaction at least once. The sample that is taken for this research is 88 respondents with purposive sampling method and Slovin. Primary data collection technique is like questionnaires with Likert Scale and secondary data is like internal company data, competitor data and related literature. Data analysis techniqueuses SEM-PLS. Based on the results of the analysis, it is found that (1) social media marketing has a significant positive effect on Haroo Table brand awareness, (2) social media marketing has a significant positive influence on Haroo Table's purchase decisions, (3) brand awareness has a significant positive influence on Haroo Table's purchase decisions and (4) brand awareness can mediate the effect of social media marketing on Haroo Table's purchase decision.
\end{abstract}

Keywords-Social Media Marketing, Brand Awareness, Purchase Decision

\section{INTRODUCTION}

Bakery product's growth is increasing time by time supported by culinary culture from other regions or nations and the development of public's expectations on bakery's product. Bakery business opportunity in Indonesia has grown rapidly and online-based business are increasingly accepted bythe public (Santoso, G. J et.al, 2018). Bread and cookies are bakery's product that keep on trend and on demand (Kementrian Pertanian, 2018). It opens up opportunity for Haroo Table to be present as a company that provide bread and cookies. Haroo Table products are home-made, made by order and use premium ingredients. Haroo Table uses social media marketing, it means marketing that uses social media to promote a product or a service. Haroo Table uses Instagram as the main platform, Instagram Ads, endorsements and Shopee as digital marketplace. Based on Haroo Table's marketing and sales report, promotional activities alone are not enough because there are competitors whose promotional activities are more attractive and already have higher brand awareness than Haroo Table.

There are two competitors that recognized by the company as threat because they have similar marketing method (social media marketing) and products. However, the competitors are more famous than Haroo Table and this proven has the potential to make the company's profit get stuck or even decline because there are more people decided to buy from a competitor. 
Companies need to manage the most appropriate social media to increase brand awarenessbecause brand awareness can trigger consumers to decide to buy a product. This statement is supported by research from Sulistio (2018) that brand awareness has a direct impact on significant effect on purchasing decision making and is the first factor that can influence customers purchase decision is brand awareness. Brand awareness may increase consumer purchasing power and profit growth company. Based on the background of the problems that have been described previously, the authors want to examine deeper into The Influence of Social Media Marketing on Purchase Decision with Brand Awareness as Mediation on Haroo Table.

\section{LITERATURE REVIEW}

\subsection{Social Media Marketing}

Social media is a digital platform for companies to do marketing activities in this modern era where consumers are actively involved in the offer, have access to comment, share and get information easily (Ansari et al., 2019). Marketing that uses social media is called social media marketing. Social media marketing is a program designed by the company to engage consumers directly or indirectly to creating brand awareness, to enhance the brand and to increase sales of the product or service. Many companies claim that social media marketing adds value, effective and efficient to introduce a product or a brand to become the choice of consumers to buy products or services offered (Kurniasari \& Budiatmo, 2018). Indicators of Social Media Marketing are: (Raharjo \& Semuel, 2018):

\section{Promotions and content attract consumers}

2. Consumers understand the promotion and content delivered

3. Promotions and content provided according to consumer's expectations

4. Consumers are encouraged to buy after seeing the promotions and content

5. Consumers are encouraged to give good testimonials.

\subsection{Brand Awareness}

Brand awareness is the ability of consumers to recognize or recall that a brand is a part of a certain product category (Raharjo \& Semuel, 2018). The definition of brand awareness is the ability of consumers to know a brand and its relationship with them. Many companies use social media as a tool to increase brand awareness level (Ardiansyah \& Sarwoko, 2020). The important role of creating brand awareness is because the majority of people find it difficult to try something new in buying or using goods and services. Stages of brand awareness: 1.Unaware of brand (not aware of the brand), 2. Brand recognize (brand recognition), 3. Brand recall (recall without assistance to the brand), 4. Top of mind. Indicators of Brand Awareness are:

1. Consumers know the brand

2. Consumers recognize brand features among other brands

3. Aware of the existence of the brand

4. Consumers visualize brand features quickly

5. Consumers quickly recognize a logo or brand symbol.

\subsection{Purchase Decision}

In purchasing, there is a process of consideration from consumers (Kurniasari \& Budiatmo, 2018), there is searching for product or brand information, references and promotion. When consumers actually make purchases product or service is called a purchase decision. Purchase decision is a process decision making by consumers in choosing goods or services 
offered in the market (Ansari et al., 2019). Purchase decision is the stage where the buyer has made his choice and make purchases of products, consume them (Upadana \& Pramudana, 2020). There are six stages of purchase decision according to Consumer Decision Making Process theory by Engel et al., (2006): 1. Need recognition, 2. Information search, 3. Evaluation of alternatives, 4. Purchase decisions, 5. Consume and 6. Post purchase behaviours. Indicators of Purchase Decisions are: (Upadana \& Pramudana, 2020)

1. Decided to choose: from a variety of bakery shops, decided to choose Haroo Tablefor bakery products

2. Priority: prioritize to buy Haroo Table's products compared to others

3. Willingness to sacrifice: willingness to sacrifice (time, money, energy) to get Haroo Table's products

4. Like the product: consumers feel satisfied after buying Haroo Table's products.

According to Upadana \& Pramudana (2020), Ardiansyah \& Sarwoko (2020), social media marketing has a positive and significant effect on brand awareness. How consumers know about a brand's brand awareness is through effective marketing like social media marketing so this study states that social media marketing has a significant and positive effect on brand awareness (Raharjo \& Semuel, 2018). Based on the explanation above, the following hypothesis can be made:

\section{H1: Social Media Marketing has a significant positive effect on Haroo Table Brand Awareness}

According to Upadana \& Pramudana (2020), Ardiansyah \& Sarwoko (2020) and Ansari et al. (2019) social media marketing has a positive and significant effect on purchase decision. Social media helps increase purchase decision, influence consumer behaviour and drive consumers to buy their products. Based on the explanation above, the following hypothesis can be made:

\section{H2: Social Media Marketing has a significant positive effect on Haroo Table's Purchase Decisions}

According to Upadana \& Pramudana (2020), Kurniasari \& Budiatmo (2018) and Firda (2019), brand awareness has a positive and significant effect on purchase decision. In the process of choosing an alternative, consumer remembers a brand in a certain product category because they know and believein the product and the brand. The higher the brand level awareness of a brand, the higher the possibility for consumers make purchases (Ardiansyah \& Sarwoko, 2020). Based on the explanation above, the following hypothesis can be made:

\section{H3: Brand Awareness has a significant positive effect on Haroo Table's Purchase Decisions}

According to Upadana \& Pramudana (2020), brand awareness has a positive and significant effect on purchase decision. Based on the explanation above, the following hypothesis can be made:

\section{H4: Brand Awareness mediates the effect of Social Media Marketing on Haroo Table's Purchase} Decision.

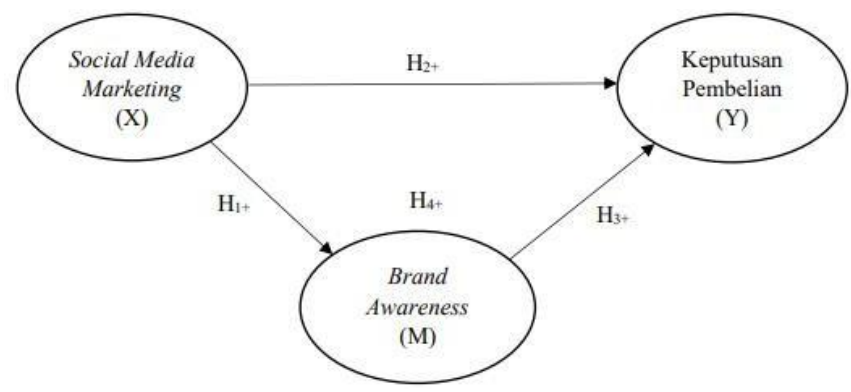

Figure 1. Haroo table's purchase decision. 
3. Research Methods

\subsection{Methods}

This research is a quantitative study. Quantitative research is a method used to examine a specific population or sample, data collection using research instruments, quantitative or statistical data analysis, with the aim of testing predetermined hypotheses. The researchers used a hypothesis to answer the problem of purchase decision in Haroo Table's products. The purpose of this data is to analyse the effect of social media marketing on purchase decision with brand awareness as a mediation.

The population in this study has the following characteristics: (1) following HarooTable's Instagram; (2) has bought Haroo Table's product at least once. Thus, the population was 112 consumers. The sample is part of the number of characteristics possessed by the population. The sample in this study was conducted using purposive sampling and Slovin. Thus, the number of samples needed for this study was 88 respondents. The data used in this study are primary data. Primary data conducted in this study were obtained directly from respondents through distributing questionnaires. In this study, 5-Likert scale used to measure the variable.

\subsection{Results}

Respondents in this study were Haroo Table's consumer who following and have bought Haroo Table before. Questionnaires were distributed online via Google form. Researchers distributed questionnaires to 88 respondents, according to the Haroo Table consumer list. The number of respondents who have filled out the questionnaire is proportional to the distributionof the questionnaire, which are 88 people.

Table 1. Respondent's Profile

\begin{tabular}{|l|l|l|l|}
\hline \multicolumn{2}{|l|}{ Profil } & Frequency & Percentage \\
\hline \multirow{2}{*}{ Gender } & Male & 27 & $30.7 \%$ \\
\cline { 2 - 4 } & Female & 61 & $69.3 \%$ \\
\hline \multirow{2}{*}{ Age } & $15-21$ & 34 & $38.6 \%$ \\
\cline { 2 - 4 } & $22-28$ & 54 & $61.4 \%$ \\
\hline
\end{tabular}

From the descriptive results of the respondent's data, it can be said that Haroo Table consumers are dominated by women with a percentage of $69,3 \%$ or as many as 61 people. Based on the age range of $22-28$ years as many as $61.4 \%$ or 54 people. The benefit of this conclusion is that Haroo Table is in more demand by female consumers with an age range of $22-28$ years old which is in accordance to the segment of the company.

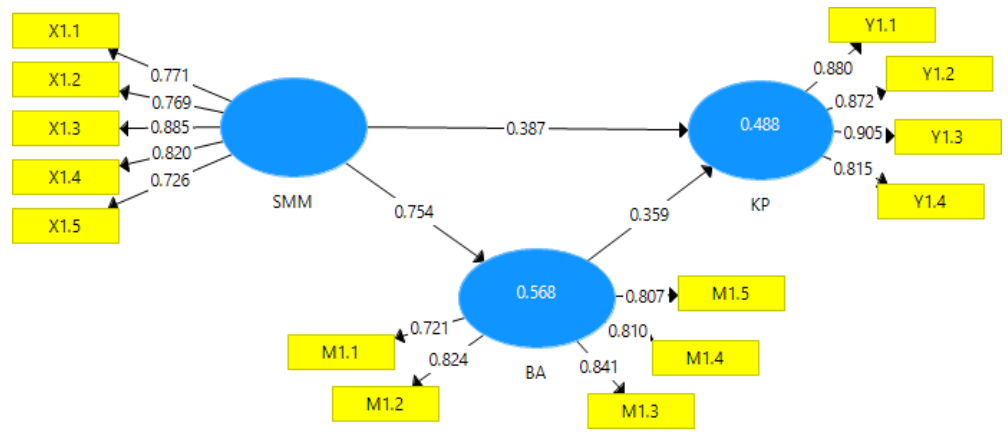

Figure 2. Structural Model - Connection between variables using PLS 
Outer model evaluation is a model to test research questionnaire's validity and reliability(Jogiyanto \& Abdillah, 2016) which is:

\section{a. Convergent Validity}

Table 2. Outer Loading Score

\begin{tabular}{|c|c|c|}
\hline Variable & Indicator & Outer Loading \\
\hline \multirow{4}{*}{ Social Media Marketing } & $\mathrm{X} 1.1$ & 0.771 \\
\cline { 2 - 3 } & $\mathrm{X} 1.2$ & 0.769 \\
\cline { 2 - 3 } & $\mathrm{X} 1.3$ & 0.885 \\
\cline { 2 - 3 } & $\mathrm{X} 1.4$ & 0.820 \\
\cline { 2 - 3 } & $\mathrm{X} 1.5$ & 0.726 \\
\hline \multirow{4}{*}{ Brand Awareness } & $\mathrm{M} 1.1$ & 0.721 \\
\cline { 2 - 3 } & $\mathrm{M} 1.2$ & 0.824 \\
\cline { 2 - 3 } & $\mathrm{M} 1.3$ & 0.841 \\
\cline { 2 - 3 } & $\mathrm{M} 1.4$ & 0.810 \\
\cline { 2 - 3 } & $\mathrm{M} 1.5$ & 0.807 \\
\hline \multirow{4}{*}{ Purchase Decision } & $\mathrm{Y} 1.1$ & 0.880 \\
\cline { 2 - 3 } & $\mathrm{Y} 1.2$ & 0.872 \\
\cline { 2 - 3 } & $\mathrm{Y} 1.3$ & 0.905 \\
\cline { 2 - 3 } & $\mathrm{Y} 1.4$ & 0.815 \\
\hline
\end{tabular}

A validity test is done to ensure that the questionnaires are used to meet the requirements of measurement and reliability. All instruments have outer loading $>0.7$.

\section{b. Discriminant Validity}

Table 3. Cross Loading Score

\begin{tabular}{|c|c|c|c|}
\hline Indikator & SMM $(\mathbf{X})$ & BA $(\mathbf{M})$ & PD $(\mathbf{Y})$ \\
\hline $\mathrm{X} 1.1$ & $\mathbf{0 . 7 7 1}$ & 0.656 & 0.613 \\
\hline $\mathrm{X} 1.2$ & $\mathbf{0 . 7 6 9}$ & 0.582 & 0.486 \\
\hline $\mathrm{X} 1.3$ & $\mathbf{0 . 8 8 5}$ & 0.685 & 0.571 \\
\hline $\mathrm{X} 1.4$ & $\mathbf{0 . 8 2 0}$ & 0.549 & 0.540 \\
\hline $\mathrm{X} 1.5$ & $\mathbf{0 . 7 2 6}$ & 0.497 & 0.360 \\
\hline $\mathrm{M} 1.1$ & 0.598 & $\mathbf{0 . 7 2 1}$ & 0.463 \\
\hline $\mathrm{M} 1.2$ & 0.618 & $\mathbf{0 . 8 2 4}$ & 0.533 \\
\hline $\mathrm{M} 1.3$ & 0.673 & $\mathbf{0 . 8 4 1}$ & 0.528 \\
\hline $\mathrm{M} 1.4$ & 0.548 & $\mathbf{0 . 8 1 0}$ & 0.471 \\
\hline $\mathrm{M} 1.5$ & 0.574 & $\mathbf{0 . 8 0 7}$ & 0.602 \\
\hline $\mathrm{Y} 1.1$ & 0.600 & 0.595 & $\mathbf{0 . 8 8 0}$ \\
\hline $\mathrm{Y} 1.2$ & 0.536 & 0.590 & $\mathbf{0 . 8 7 2}$ \\
\hline $\mathrm{Y} 1.3$ & 0.563 & 0.548 & $\mathbf{0 . 9 0 5}$ \\
\hline $\mathrm{Y} 1.4$ & 0.583 & 0.525 & $\mathbf{0 . 8 1 5}$ \\
\hline
\end{tabular}

Each indicator has the value of cross loading on the measured variable is greater than the other variables.

Table 4. AVE Score

\begin{tabular}{|c|c|}
\hline Variabel & AVE \\
\hline Social Media Marketing & 0.634 \\
\hline Brand Awareness & 0.642 \\
\hline Purchase Decision & 0.755 \\
\hline
\end{tabular}

The AVE value of each variable has a value of $>0.5$ which means that each variablehas met the requirements.

\section{c. Reliability}

Table 5. Reliability Score

\begin{tabular}{|c|c|c|}
\hline Variabel & $\begin{array}{c}\text { Cronbach } \\
\text { Alpha }\end{array}$ & $\begin{array}{c}\text { Composite } \\
\text { Reliability }\end{array}$ \\
\hline Social Media Marketing & 0.855 & 0.896 \\
\hline Brand Awareness & 0.860 & 0.899 \\
\hline Purchase Decision & 0.891 & 0.925 \\
\hline
\end{tabular}

The Cronbach Alpha score of each variable is $>0.6$ and the Composite Reliability score of each variable is $>0.7$, so it can be concluded that each variable has met the reliability of the model. 
Inner model evaluation is structural model that connects between variables and inhypothesis testing are used as parameters significance (Vasthi, 2020) which is:

\section{a. R-Square $\left(\boldsymbol{R}^{2}\right)$}

Table 6. R-Square Score

\begin{tabular}{|c|c|}
\hline Variable & R-Square \\
\hline Brand Awareness & 0.565 \\
\hline Purchase Decision & 0.499 \\
\hline
\end{tabular}

The R-Square score for the Brand Awareness variable is 0.565, which means that Social Media Marketing can influence Brand Awareness by $56.5 \%$ and the rest is explained by other factors not examined in this study. The same interpretation for the R-Square purchasing decision variable is 0.499 which means that Social Media Marketing and Brand Awareness can influence Purchase Decision by $49.9 \%$ while the rest is explained by other factors not examined in this study.

b. Q-Square $\left(Q^{2}\right)$

$$
\begin{aligned}
\text { Q-Squar } & =1-(1-0.565) \times(1-0.499) \\
& =0.79
\end{aligned}
$$

Q-Square result show that this research model has good predictive accuracy. This research model can predict $79 \%$ of Haroo Table's consumer purchasing decisions, while the remaining $21 \%$ is explained by other factors outside of this study.

Based on the data processing, the results are used to answer the hypothesis in the study.The research hypothesis can be accepted if the T-Statistic value is $>1.96$ and the P Values is $<0.05$.

Table 7. T-Statistic \& P-Values Score

\begin{tabular}{|c|c|c|c|}
\hline Hypothesis & T-Statistic & P-Values & Result \\
\hline H1 & 3.047 & 0.001 & Accepted \\
\hline H2 & 15.103 & 0.000 & Accepted \\
\hline H3 & 3.559 & 0.003 & Accepted \\
\hline
\end{tabular}

The T-Statistic and P-Values values of the three hypotheses is valid. Therefore, the three hypotheses proposed in this study can be accepted.

The mediating effect of the Brand Awareness variable can be determined by calculating the VAF (Variance Accounted For) with the criteria of VAF > 80\% (full mediation), 20\%- 80\% VAF (partial mediation) and $\mathrm{VAF}<20 \%$ (not mediating).

Table 8. VAF Score

\begin{tabular}{|l|c|}
\hline Indirect Effects & 0.271 \\
\hline Social Media Marketing $\rightarrow$ Brand Awareness $\rightarrow$ Purchase Decision & 0.754 \\
\hline Direct Effects & 0.387 \\
\hline Social Media Marketing $\rightarrow$ Brand Awareness & 0.359 \\
\hline Social Media Marketing $\rightarrow$ Purchase Decision & 0.658 \\
\hline Brand Awareness $\rightarrow$ Purchase Decision & 0.411 \\
\hline Total Direct & $\begin{array}{l}\text { Social Media Marketing, Brand Awareness, Purchase Decision } \\
(0.271+0.387)\end{array}$ \\
\hline VAF &
\end{tabular}

Brand Awareness as a mediator between the influence of Social Media Marketing on the Haroo Table Purchase Decision is 0.411 or $41.1 \%$ and that value is included in partial mediation. 
4. Result and Discussion

The results of the path coefficient value on the social media marketing on brand awareness show a value of 0.754 which states that social media marketing has a positive effect on brand awareness. Then, the results of the relationship between social media marketing on brand awareness have at value statistical of 3.047 which is greater than the $\mathrm{T}$ value table which means $\mathrm{H} 1$ is significant so that the first hypothesis (H1) that stated that the social media marketing has a significant effect on brand awareness is accepted. The source of brand awareness is a well promotion (Nadhiro, 2019). Social media marketing is very helpful in introducing and educating the existence of a brand into consumer choice. The results of the research are in accordance with and support previous research conducted by Upadana \& Pramudana (2020), Ardiansyah \& Sarwoko (2020).

The results of the path coefficient value on the social media marketing on purchase decision show a value of 0.387 which states that social media marketing has a positive effect on purchase decision. Then, the results of the relationship between social media marketing on purchase decision have at value statistical of 15.103 which is greater than the T value table which means $\mathrm{H} 2$ is significant sothat the first hypothesis $(\mathrm{H} 2)$ that stated that the social media marketing has a significant effect on purchase decision is accepted. Social media marketing has an important role in building connection with customers (Ansari et al., 2019), it will creating consumer's participate, influence consumer's purchase behaviour and will lead towards improving purchase decision. The results of the research arein accordance with and support previous research conducted by Upadana \& Pramudana (2020), Ardiansyah \& Sarwoko (2020) and Ansari et al., (2019).

The results of the path coefficient value on the brand awareness on purchase decision show a value of 0.359 which states that brand awareness has a positive effect on purchase decision. Then, the results of the relationship between brand awareness on purchase decision have at value statistical of

3.559 which is greater than the $\mathrm{T}$ value table which means $\mathrm{H} 3$ is significant so that the first hypothesis $(\mathrm{H} 3)$ that stated that the brand awareness has a significant effect on purchase decision is accepted. The conclusion is that consumers pay attention to aspects of product innovation which consist of 'design change', 'technical innovation', and 'product development'. Consumers are more satisfied if Mr. Sei can make changes to the logo shape design with a newer one. The results of the research are in accordance with and support previous research conducted by Upadana \& Pramudana (2020), Kurniasari \& Budiatmo (2018) and Firda (2019).

The results of the Variance Accounted For (VAF) of the brand awareness mediates the effect of social media marketing on purchase decision shows a value of 0.411 or $41.1 \%$, which means partial mediation, so that the fourth hypothesis (H4) stating that brand awareness mediates the effect of social media marketing on purchase decision is accepted. The conclusion from the results of this study is in accordance with and supports previous research conducted by Upadana \& Pramudana (2020).

\section{Conclusions and Practical Implication}

a. The results of the PLS analysis:

- T-Statistic value of the influence of social media marketing to brand awareness is greater than 1.96, which is 3,047 so it can be concluded that social media marketing has significant positive effect on Haroo Table's brand awareness. The higher social media marketing will increase Haroo Table brand awareness.

- T-Statistic value of the influence of social media marketing on purchase decision is greater than 1.96, which is 15.103 so it can be concluded that social media marketing has significant 
positive effect on Haroo Table's purchase decision. The higher social media marketing will increase Haroo Table purchase decision.

- T-Statistic value of the influence of brand awareness on purchase decision is greater than 1.96, which is 3.559 so it can be concluded that brand awareness has significant positive effect on Haroo Table's purchase decision. The higher brand awareness will increase Haroo Table purchase decision.

- VAF calculation's result is 0.411 or 41.1 so it can be concluded that brand awareness mediates the effect of social media marketing on Haroo Table's purchase decision. When social media marketing applied by the company is in line with consumer's expectations, it will increase brand awareness, then improve purchase decision.

b. There are three managerial implications:

- Based on the respondent's profile, Haroo Table is in more demand by female consumers with an age range of $22-28$ years old which is in accordance to the segment of the company but the segment can be enlarged again with the right promotion method, for example the determination of Instagram Ads to spread posts, attract more consumers and achieve greater profit.

- Based on the results of the average respondents' answers to brand awareness are statement "Saya dapat mengenali ciri merek Haroo Table di antara merek lain" is still in the agree and good category but the average score of this statement is smaller than the other statements in the results questionnaire. This shows that the company's brand characteristics are still can be improved again by highlighting the company's uniqueness like social media content and concept or products and packaging's details that are unique and different from competitors.

- Based on the results of the role of brand awareness as a partial mediation, Haroo Table should increase brand awareness until "top of mind" level by using social media marketing according to consumer's preference to improve purchase decision.

\section{REFERENCES}

Abdillah, W., \& Jogiyanto, H. (2015). Partial Least Square (PLS) Alternatif Structural Equation Modeling (SEM) dalam Penelitian Bisnis. In book.

Ansari, S., Ansari, G., Ghori, M. U., \& Kazi, A. G. (2019). Impact of brand awareness and social media content marketing on consumer purchase decision. Journal of Public Value and Administration Insights, 2(2), 510. https://doi.org/10.31580/jpvai.v2i2.896

Ardiansyah, F., \& Sarwoko, E. (2020). How social media marketing influences consumers purchase decision? A mediation analysis of brand awareness. JEMA: Jurnal Ilmiah Bidang Akuntansi Dan Manajemen, 17(2), 156. https://doi.org/10.31106/jema.v17i2.6916

Bilgin, Y. (2018). The effect of social media marketing activities on brand awareness, brand image and brand loyalty. Business \& Management Studies: An International Journal, 6(1), 128-148. https://doi.org/10.15295/bmij.v6i1.229

Chin, W., Esposito Vinzi, V., Henseler, J., \& Wang, H. (2010). Handbook of partial least squares: Concepts, methods and applications. International Journal of Nursing Studies - INT J NURS STUD. https://doi.org/10.1007/978-3-540-32827-8

Ferdinand, A. (2014). Metode Penelitian Manajemen, Semarang. Badan Penerbit Universitas Diponegoro.

Firda, R. (2019). Peran brand awereness terhadap keputusan pembelian produk. Jurnal StudiManajemen Dan 
Ghozali \& Latan. (2015). Partial Least Square SEM (PLS - SEM). Partial Least Square.

Hair, J. F., Hult, G. T. M., Ringle, C. M., Sarstedt, M., Hopkins, L., \& Kuppelwieser, V. G. (2014). A Primer on Partial Least Squares Structural Equation Modeling. Sage.

Hair, J., Sarstedt, M., \& Ringle, C. (2017). Partial Least Squares Structural Equation Modeling. https://doi.org/10.1007/978-3-319-05542-8 15-1

Hasan, M., \& Sohail, M. S. (2020). The Influence of Social Media Marketing on Consumers'Purchase Decision: Investigating the Effects of Local and Nonlocal Brands. Journal of International Consumer Marketing, O(0), 1-18. https://doi.org/10.1080/08961530.2020.1795043 Hikmareta, A., \& Zuliestiana, D. A. (2020). Pengaruh Social Media Marketing Pada InstagramTerhadap Purchase Intention Melalui Brand Awareness Sebagai Variabel Mediasi (Studi kasus pada followers aktif akun Instagram Alpucard Online Printing). 7(2), 2485-2492.

Kementrian Pertanian. (2018). Statistik Konsumsi Pangan.

Kim, J., Melton, R., Min, J. E., \& Kim, B. Y. (2020). Who says what?: exploring the impacts of content type and blog type on brand credibility, brand similarity and eWOM intention. Journal of Fashion Marketing and Management, 24(4), 611-630. https://doi.org/10.1108/JFMM-03-2019-0041

Kurniasari, M., \& Budiatmo, A. (2018). Pengaruh Social Media Marketing, Brand Awareness Terhadap Keputusan Pembelian Dengan Minat Beli Sebagai Variabel Intervening Pada J.Co Donuts \& Coffee Semarang. Diponegoro Journal of Social Adn Politic, 1-7.

Maswar, M. (2017). Analisis Statistik Deskriptif Nilai UAS Ekonomitrika Mahasiswa dengan Program SPSS 23 \& Eviews 8.1. Jurnal Pendidikan Islam Indonesia. https://doi.org/10.35316/jpii.v1i2.54

Nadhiro. (2019). Pengaruh Social Media Marketing Terhadap Brand Awareness Pada Followers Instagram Warunk Upnormal. Universitas Negeri Surabaya, 02(02), 88-92.

Raharjo, S. T., \& Samuel, H. (2010). Pengaruh Social Media Marketing Terhadap Purchase Intentionmelalui Brand Awareness Sebagai Variabel Mediasi pada Lazada. 1-6.

Santoso, G. J., Wahyudi, A., Soeparto, H., \& Soetedja, V. (2018). Pembelian Tiket Pengunjung Honda DBL Surabaya. PERFORMA: Jurnal Manajemen Dan Start-Up Bisnis, 3(5).

Shahid, Z., Hussain, T., Park, N. C., Bagh, T., \& Scheme, H. (2017). The Impact of Brand Awareness on The consumers ' Purchase Brand Knowledge Brand Equity Brand Loyalty Percieved Quality Brand Awareness Brand Image. Journal of Marketing and Consumer Research, 33, 34-38.

Stojanovic, I., Andreu, L., \& Curras-Perez, R. (2018). Effects of the intensity of use of social mediaon brand equity: An empirical study in a tourist destination. European Journal of Management and Business Economics, 27(1), 83-100. https://doi.org/10.1108/EJMBE-11-2017-0049

Sugiyono. (2018). Metode Penelitian Kuantitatif,Kualitatif dan R\&D. Ke-26.

Sulistio, A. (2018). Pengaruh Promotion Mix Terhadap Brand Awareness PT HM Sampoerna Tbk Melalui Produk Terbaru Sampoerna A Platinum. Jurnal Strategi Pemasaran, 5(2), 1-7. Retrieved from 
Upadana, M. wahyu K., \& Pramudana, K. A. S. (2020). Brand Awareness Memediasi Pengaruh Social Media Marketing Terhadap Keputusan Pembelian. E-Jurnal Manajemen Universitas Udayana, 9(5), 1921. https://doi.org/10.24843/ejmunud.2020.v09.i05.p14 